$\xi=-1$

\title{
Lean Manufacturing as a Way of Employees' Motivation in Energy Saving
}

\author{
Olga Viktorovna Lenkova ${ }^{1} *$, Anatolij Dmitrievich $\operatorname{Kot}^{2}$, Olga Gennadievna Yakunina ${ }^{3}$, Maxim Semyonovich \\ Yumsunov $^{4}$
}

\author{
${ }^{I}$ Federal State Budget Educational Institution of Higher Education "Industrial University of Tyumen", \\ Volodarskogo St., 38, Tyumen, 625000, Russia \\ ${ }^{2}$ Federal State Budget Educational Institution of Higher Education "Industrial University of Tyumen", \\ Volodarskogo St., 38, Tyumen, 625000, Russia \\ ${ }^{3}$ Federal State Budget Educational Institution of Higher Education "Industrial University of Tyumen", \\ Volodarskogo St., 38, Tyumen, 625000, Russia \\ ${ }^{4}$ Federal State Budget Educational Institution of Higher Education "Industrial University of Tyumen", \\ Volodarskogo St., 38, Tyumen, 625000, Russia
}

\begin{abstract}
The article indicates the importance of cost management in general, and energy consumption, in particular, at the enterprises of main oil transportation. For this purpose, it is necessary to search for losses in production processes and develop solutions for their elimination. The concept of "lean production", adapted to the industry features, is suggested as the main method of solving this problem. It outlines the importance of involving employees in the development of the strategy and motivation to search for losses and their elimination. In order to identify the awareness and motivation of employees for energy saving and rationalization, a questionnaire was developed. The results of the survey at one of the production departments of the oil transport enterprise are given. The work also presents a fragment of the Ishikawa diagram used to identify the reasons of the employees' insufficient interest in saving energy. The article covers the results of the study of the existing motivational policy of the organization and the research data of existing practices of constructing motivational systems in organizations in other spheres. Recommendations are given for adjusting the existing motivation system in the enterprise under study. An approximate plan for the implementation of the project proposals is suggested, and the directions for further research within the field are formulated.
\end{abstract}

Keywords: lean production, motivation, savings, losses.

\section{Introduction}

High energy expenditures in the structure of prime costs of oil and oil products transportation, increasing tariffs for energy carriers and targets of the strategic development program of OAO AK Transneft predetermine the need to continuously search for and mobilize the reserves of energy consumption reduction. While energy costs should be considered not only as costs of the main production, connected mostly with the equipment operation, but also energy costs in the additional, service units, and in the administration (management).

Energy saving involves, on the one hand, the search for more economical and technological innovation solutions, and, on the other hand, the elimination of unnecessary costs (losses). In any case, the main source of knowledge about possible losses and/or opportunities for technical or technological improvement is a person directly involved in the production, maintenance or management process. In this regard, it can be argued that the effectiveness of the energy saving policy depends on the level of motivation of employees.

In this context, it seems interesting to consider the possibility of using the concept of lean manufacturing at the oil transport enterprise, which has been successfully implemented at many large Russian enterprises in various spheres (OAO RZhD, OAO Sberbank, etc.).

\section{Methods}

The main activities of OAO Transneft are oil and oil products transportation through the system of main pipelines in the Russian Federation and beyond, as well as dispatching the supply of oil and oil products. In addition, the company provides oil storage services in the system of main pipelines, oil compounding, oil sales, planning and management of oil transportation on the territory of foreign countries and oil delivery at foreign acceptance points, organizes collection and compilation of information. Transneft provides consistent oil intake from oil and gas producing enterprises, transportation through the system of trunk oil pipelines through the territory of the Russian Federation and delivery to recipients.

The analysis shows, that over the past ten years there has been a steady trend of growth in tariffs for oil pumping on average by 12$13 \%$ per year. At the same time, the corporate strategic development program forecasts an increase in transportation volumes while reducing unit costs (Table 1). 
Table 1. Strategic Development Program Targets OAO "Transneft" (fragment)

\begin{tabular}{|c|c|c|}
\hline \multirow{2}{*}{ Indicator, unit measure } & Actual value & Planned value \\
\hline & in 2011 & by 2020 \\
\hline Transportation volume of Russian and transit oil, mln. tons per year & 473,9 & 496,3 \\
\hline Transportation volume of petroleum products, mln. tons per year & 30 & 54,5 \\
\hline Length of main oil pipeline system, $\mathrm{km}$ & 53441 & 54941 \\
\hline Length of main oil pipeline system, $\mathrm{km}$ & 19167 & 21447 \\
\hline Specific electricity consumption for pumping oil in set conditions, $\mathrm{kW}^{*} \mathrm{~h} /$ thousand tons $* \mathrm{~km}$ & 12,53 & 11,32 \\
\hline $\begin{array}{l}\text { Unit costs for } 100 \text { tkm without considering depreciation allowances in prices of } 2010 \text {, rubles } / 100 \\
\text { tkm }\end{array}$ & 16,7 & 14,1 \\
\hline Unit costs for $100 \mathrm{tkm}$ without considering depreciation allowances (in interest rates), \% & 18,8 & 27,4 \\
\hline
\end{tabular}

Source: Strategic Development Program of OAO AK Transneft for the period until 2010 (Approved by the decision of the Board of Directors of OAO AK Transneft (Minutes No. 2 of 31.01.2012)) http://www.transneft.ru/about/development-system/398

Whereas, in the structure of the prime cost of main oil transportation, about $40 \%$ is spent on energy costs, which are used in all production segments (Fig. 1).

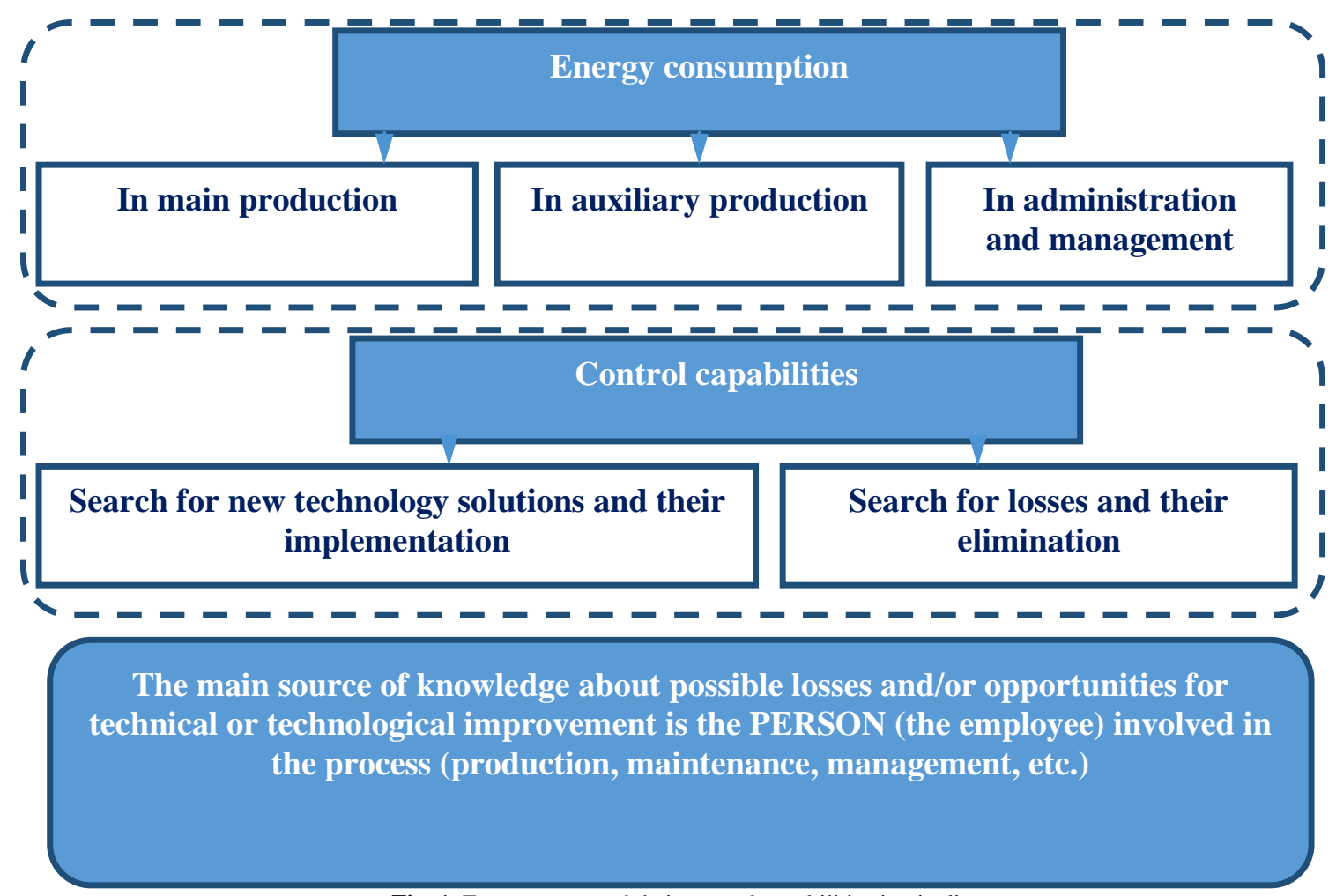

Fig. 1. Energy costs and their control capabilities in pipeline transport

In this regard, it seems interesting to consider the possibilities of lean production, which in the most general view implies the concept of managing a production enterprise based on a constant striving to eliminate all types of losses and considers involving each employee in the process of business optimization. There are many tools in the concept of lean manufacturing, among which, Kaizen should be mentioned the philosophy or practice that focuses on the continuous improvement of production processes. Most Kaizen principles are aimed at the organization's personnel and assume its direct involvement in the processes of improving the company's operations.

The analysis of the staff motivation system at the oil transport enterprise was carried out using various methods. Local regulatory acts that regulate the payment and incentives, in terms of motivating creative/rationalizing activities, were studied. The results of this study allow us to talk about the crudity of the mechanism of organization and rewarding rationalization in the organization.
Also, a survey was carried out among the company's employees to determine the degree of their awareness of the possibilities of innovations and their rewarding in the organization (Figure 2). 


\section{Dear respondent, in order to study the level of staff motivation to save energy resources, we ask you to answer the following questions as objectively as possible:}

\section{Your gender:}

Your age:

Name of the division/department:

1) Do you think there are any production processes that can be simplified and, thus, save your time (or save other resources of the enterprise)?

a) Yes, of course;

b) It is possible;

c) No, the system works accurately and seamlessly.

2) Have you ever had an idea on how to reduce the time loss (or reduce the cost of other resources) in performing certain work processes?

a) Yes, pretty often;

b) I thought about it several times;

c) No, never.

3) If you answered "yes" to question №2, did you report your ideas to your supervisor?

a) Yes, my ideas have been implemented;

b) Yes, my proposal was considered, but not implemented;

c) Yes, but my proposal was not considered;

d) No, it does not make sense (I'm not interested in this);

e) No, I do not know who to report;

e) Other (please specify).

4) ...

Figure 2. A questionnaire to identify employees' awareness of the possibilities of innovations and its rewarding in the organization (fragment)

The results of the survey are shown in Figure 3.

1. Do you think there are any production processes that can be simplified and, thus, save your time (or save other resources of the enterprise)?

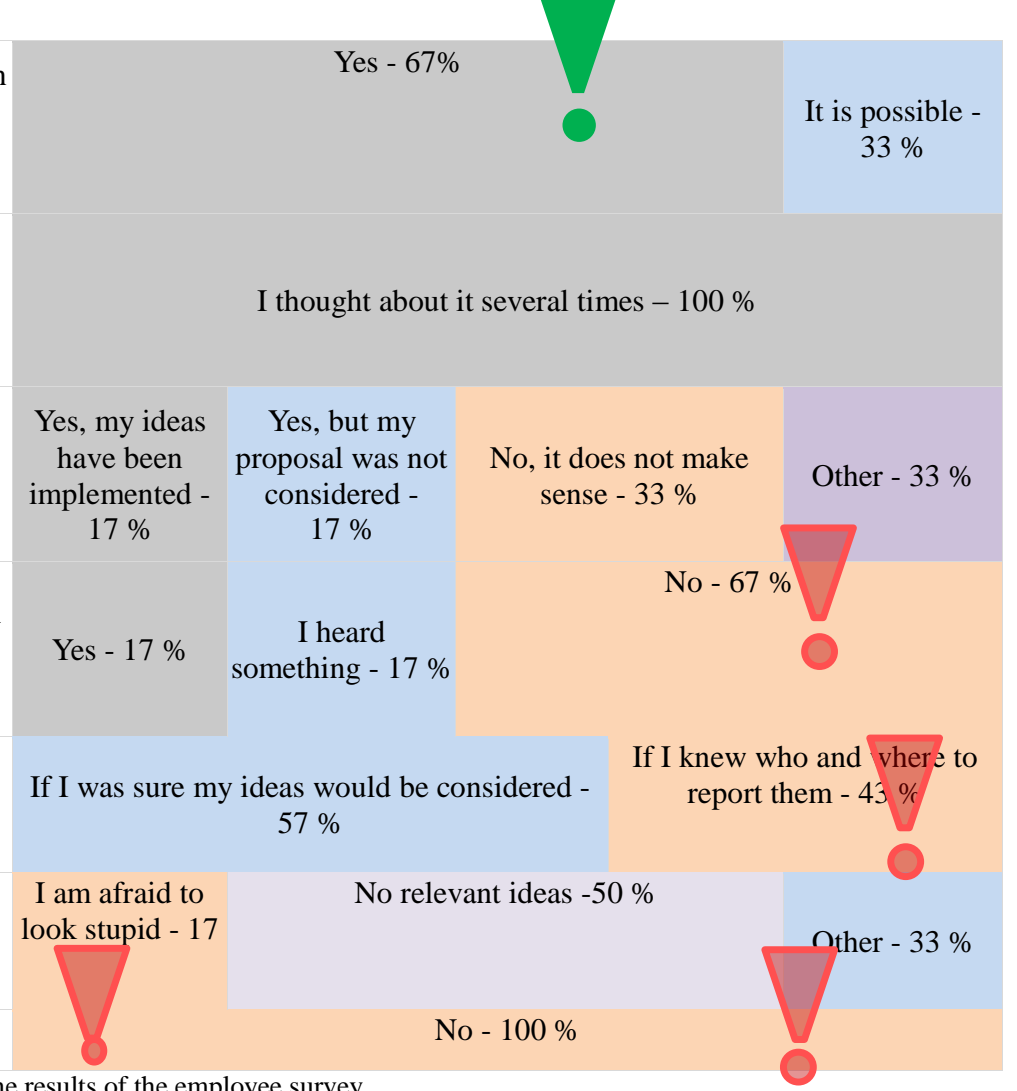

2. Have you ever had an idea on how to reduce the time loss (or reduce the cost of other resources) in performing certain work processes?

3. If you answered "yes" to question №2, did you report your ideas to your supervisor?

4. Do you know about the possibility of receiving a reward for innovations (introduction of rationalization proposals) in your organization?

5. In what case would you propose your own ideas for improving the production process?

6. What stops you from sharing the ideas?

7. Have you ever received a reward for innovative ideas?

Fig.3. The results of the employee survey

The results of the analysis show, that the enterprise has certain problems with motivation. Thus, a lot of employees are not aware of the possibility of getting a compensation for their rationalization proposals, many do not know who to talk to when they have such ideas, whereas the improvement ideas arise for all employees.
To continue the study, the Ishikawa diagram was constructed. It helps to identify the reasons for low interest and involvement in the processes of solving the energy saving problem. 


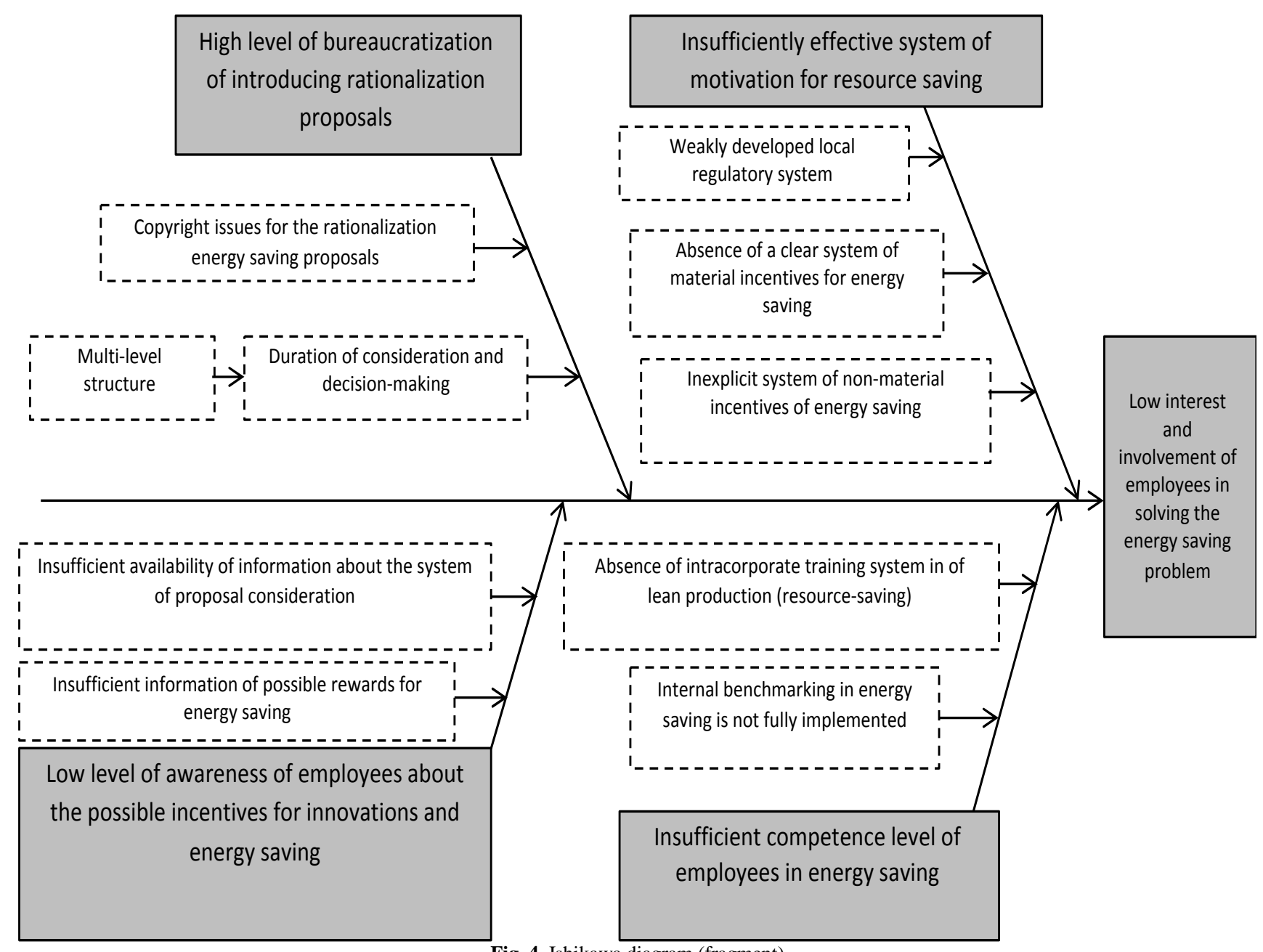

Fig. 4. Ishikawa diagram (fragment)

Along with the study of the problems in the staff innovation motivation system, benchmarking was conducted in the organization under study - a similar experience in other organizations was studied. From the point of view of possible copying the most interesting was the practice implemented by OAO RZhD, primarily for its accessibility.

\section{Results}

After the systematization of the results of the analysis of practices implemented in different companies, it was possible to form recommendations for the oil transportation enterprise under study. The recommendations should help to increase the staff creative activity in the search for energy saving solutions: training of employees in the basics of lean manufacturing, implementation of consulting in the workplace, adjustment of the relevant regulatory system, etc. Table 5 presents relevant recommendations and an approximate schedule for their implementation.

Table 5. Recommendations for improving the motivation system in the oil transport enterprise

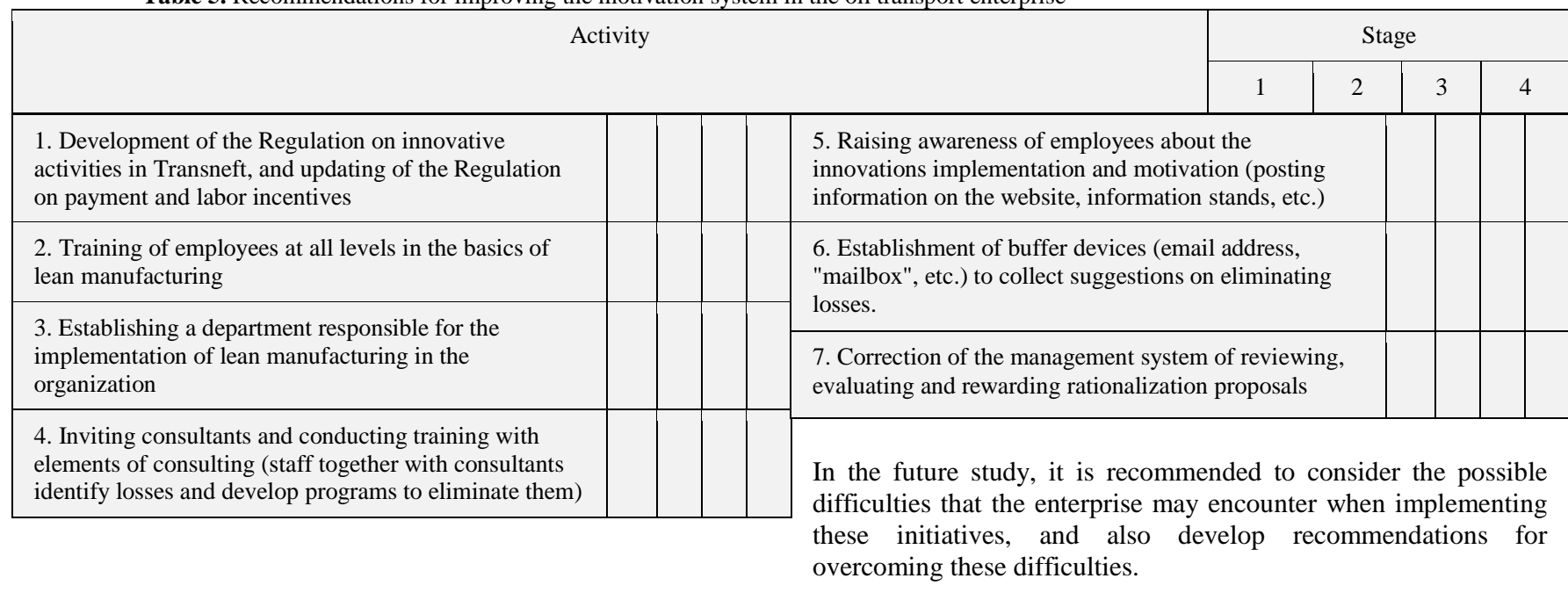




\section{Discussion}

A considerable number of researchers studying lean manufacturing are currently considering mostly general issues, without taking into account the specific character of industry functioning. Some authors consider lean production as one of the components of the development of production systems [3]. Some studies focus on lean production in connection to sustainable development [1] or in connection to increasing operational efficiency [22]. Most authors tend to consider lean production as an independent concept of improving the organizations' efficiency $[4,11,10,13,14,19,21]$.

Many domestic and foreign scientists devote their works to the examination of specific lean manufacturing tools: six sigma [6], Kanban [15], a map of value formation stream [5,8] or a set of tools in general [20]. Some works consider the issues of technology and organization of the lean manufacturing practical implementation principles $[7,17]$ the problems of assessing the feasibility and effectiveness of the lean manufacturing implementation tools $[2,16,18]$, and also the practical implementation issues in terms of problems arising during the implementation of this concept [9].

The study of existing scientific and methodological sources allows to conclude that there is a lack of information in the domestic and foreign literature on the motivation of employees for innovations.

\section{Conclusion}

In the framework of this study, the ambiguity and importance of staff participation in the development and implementation of lean manufacturing principles, in particular, in the oil transportation enterprise, is proved. Thus, the employees directly involved in technological processes, usually reveal losses in production and can generate ideas for their elimination. In this case, an effective system of staff motivation for resource-saving is very important. At the same time, the features of the enterprise operation, usually affecting the cost structure, will indicate which resources are to be saved first.

A questionnaire was created to conduct a survey among the organization's employees on the awareness of the possibilities to receive a reward for rationalization proposals, as well as on organizational aspects: the procedure for filling out an application for an invention, considering proposals, etc. The reasons for the low interest of employees in inventing activity are revealed. It is recommended to use the benchmarking capabilities to update the motivation system in order to consider the need to stimulate innovation. In the future study, it is planned to specify the recommendations, in particular, to clarify the methods for calculating the amount of reward, forming a management model for receiving and reviewing staff proposals, creating conditions for continuous improvement (Kaizen), identifying risks of implementing the proposed model, and developing recommendations for their elimination.

\section{References}

[1] A.A. Abrosimova, Svyaz' berezhlivogo proizvodstva s ustoychivym razvitiem promyshlennykh predpriyatiy [Relation of Lean Production to Sustainable Development of Industrial Enterprises] Rossiyskoe predprinimatel'stvo, 24 (246), 2013, pp. $78-83$

[2] S.A. Antonov, Kompleksnaya otsenka rezul'tativnosti berezhlivogo proizvodstva [Complex estimation of lean production efficiency] Standarty i kachestvo, 9, 2016, pp. $86-89$.

[3] A.V. Baranova, Razvitie proizvodstvennykh sistem. Kaydzen. Liderstvo. Berezhlivoe proizvodstvo [Development of produc- tion systems. Kaizen. Leadership. Lean production]. Moscow: Piter, 2015, pp. 272.

[4] N.S. Davydova, Berezhlivoe proizvodstvo [Lean production] Monograph. Izhevsk: GOUVPO «UdGU», 2012, pp. 138.

[5] S.K. Fomichev, N. I. Skryabina, O. Yu, Urazlina, Berezhlivoe upravlenie: upravlenie potokami sozdaniya tsennosti [Lean management: the management of value streams]. Metody menedzhmenta kachestva, 7, 2004, pp. 15-21.

[6] M. George, Berezhlivoe proizvodstvo + shest' sigm v sfere uslug. Kak skorost' berezhlivogo proizvodstva i kachestvo shesti sigm pomogayut sovershenstvovaniyu biznesa [Lean Six Sigma for Service: How to Use Lean Speed and Six Sigma Quality to Improve Services and Transactions]. 2011, pp. 464

[7] D.P. Hobbs, Vnedrenie berezhlivogo proizvodstva [Lean Manufacturing Implementation: A Complete Execution Manual for Any Size Manufacturer]. Minsk: Grevtsov Pablisher, 2007, pp. 351.

[8] S.V. Khodyrevskaya, Karta potoka sozdaniya tsennosti [Flow map of value creation: practical use]. Standarty i kachestvo, 3 2015 , pp. $88-89$.

[9] V. Kudryashov, Berezhlivoe proizvodstvo: problemy i opyt vnedreniya [Lean production: problems and experience of implementation] Metody menedzhmenta kachestva, 4, 2013, pp. 4-9.

[10] W.A. Levinson, R. A. Rerick, Berezhlivoe proizvodstva: sinergeticheskiy podkhod k sokrashcheniyu poter' [Lean Enterprise: A Synergistic Approach to Minimizing Waste]. RIA: «Standarty i kachestvo», 2007, pp. 272.

[11] J.K. Liker, DAO Toyota. 14 printsipov menedzhmenta vedushchey kompanii mira [The Toyota Way: 14 Management Principles from the World's Greatest Manufacturer]. 2nd edition. Moscow: Al'pina Biznes Buks, 2006, pp. 401

[12] V. Livshits, Vek berezhlivogo proizvodstva - Lean manufacturing [Age of Lean manufacturing]. Retrieved from: http://proza.ru/2007/03/25-282.

[13] T. Luyster, D. Tapping, Berezhlivoe proizvodstvo: ot slov k delu [Creating Your Lean Future State: How to Move from Seeing to Doing] Moscow: Standarty i kachestvo, 2008, pp. 128

[14] D. Mann, Berezhlivoe upravlenie berezhlivym proizvodstvom [Creating a Lean Culture: Tools to Sustain Lean Conversions] Translated from English. Moscow: Standarty i kachestvo, 2009, pp. 208.

[15] R. Odintsova, Primenenie osnovnykh printsipov berezhlivogo proizvodstva i instrumentov Lean i Kanban na predpriyatiyakh neftegazovogo kompleksa [Application of Lean and Kanban's Lean Manufacturing Principles and Instruments at Oil and Gas Complexes]. Problemy ekonomiki i upravleniya neftegazovykh kompleksov, 7, 2015, pp. 29-33.

[16] I.N. Omelchenko, S. G. Komarova, S.V. Lazarev, Sistema pokazateley otsenki effektivnosti promyshlennogo predpriyatiya pri vnedrenii berezhlivogo proizvodstva [System of indicators of the assessment of the efficiency of an industrial enterprise in the introduction of lean production]. Menedzhment $\mathrm{v}$ Rossii i za rubezhom, 6, 2014, pp. 71-85.

[17] D. Pascal, Osnovy berezhlivogo proizvodstva. Putevoditel' po samoy effektivnoy v mire sisteme proizvodstva [Fundamentals of Lean Production. A guide to the most efficient production system in the world]. Moscow: Olimp-Biznes, 2013, pp. 224.

[18] N.A. Vitchuk, Raschet effektivnosti vnedreniya instrumentov berezhlivogo proizvodstva [Calculation of the effectiveness of the introduction of lean tools] Standarty i kachestvo, 11, 2015 pp. 60-63.

[19] V Vyalov, Berezhlivoe proizvodstvo [Lean Production] Textbook. Komsomolsk-on-Amur: FGBOU VPO «KnAGTU», 2014, pp. 100.

[20] M. Wader, Instrumenty berezhlivogo proizvodstva [Lean Tools: A Pocket Guide to Implementing Lean Practices]. Moscow: Al'pina Pablisher, 2011, pp. 124

[21] J.P. Womack, Berezhlivoe proizvodstvo: kak izbavit'sya ot poter' i dobit'sya protsvetaniya vashey kompanii [Lean Thinking: Banish Waste and Create Wealth in Your Corporation]. Moscow: Al'pina Pablisher, 2013, pp. 470

[22] O.B. Zakharov, Berezhlivoe proizvodstvo kak instrument povysheniya operatsionnoy effektivnosti [Lean production as a too to improve operational efficiency] Sertifikatsiya, 2, 2016. pp. $14-19$. 